\title{
Perlindungan Hukum Hak Kekayaan Intelektual Bagi Produk Kreatif Usaha Kecil Menengah Di Yogyakarta ${ }^{1}$
}

\author{
Dyah Permata Budi Asri \\ Fakultas Hukum Universitas Janabadra Yogyakarta \\ Jln. Timoho II No.40 Yogyakarta \\ dyahpermata55@gmail.com
}

Received: 30 September 2019; Accepted: 28 Februari 2020; Published: 29 Juni 2020

DOI: 10.20885/iustum.vol27.iss1.art7

\begin{abstract}
There is a rather large presence of Small and Medium Enterprises (SMEs) as part of creative industry in Yogyakarta, yet the Intellectual Property Rights management is still very minimum. The problems in this study are, first, why the protection of Intellectual Property Rights is important for small and medium business entities as creative industries in the Special Region of Yogyakarta. Second, how is the role of the regional government of the Special Region of Yogyakarta in order to provide legal protection for Intellectual Property Rights to small and medium businesses in the special Region of Region Yogyakarta. This paper applies a juridical-empirical approach by using primary data. This study concludes that firstly, the potential market for creative industries has a tendency to develop continuously, since SMEs in Yogyakarta contribute 59\% of Gross Domestic Revenue in Special Region of Yogyakarta hence the protection of IPRs on creative economic products to guarantee the economic rights of the creators is crucial. Secondly, the role of local governments at the moment in the context of providing IPR protection for SMEs is carried out by establishing an Intellectual Property Management Center (BPKI), and developing a website to provide IPR services, namely "JogjaKI".
\end{abstract}

Keywords: Intellectual property rights; legal protection; IPR services; SME's

Abstrak

Keberadaan Usaha Kecil Menengah (UKM) sebagai industri kreatif di Yogyakarta cukup banyak, namun pengelolaan Hak Kekayaan Intelektualnya masih cenderung minim. Permasalahan dalam penelitian ini adalah, pertama, mengapa pelindungan hukum Hak Kekayaan Intelektual penting bagi usaha kecil menengah sebagai industri kreatif di Daerah Istimewa Yogyakarta. Kedua, bagaimana peran pemerintah daerah Daerah Istimewa Yogyakarta dalam rangka memberikan pelindungan hukum Hak Kekayaan Intelektual kepada usaha kecil menengah di Daerah Istimewa Yogyakarta. Penelitian ini menggunakan tipe yuridis-empiris dengan menggunakan data primer. Penelitian ini menyimpulkan pertama, potensi pasar karya industri kreatif memiliki kecenderungan terus berkembang, sebagaimana UKM di Yogyakarta yang menyumbang sebesar 59\% Pendapatan Domestik Bruto di DIY sehingga pelindungan HKI atas produk ekonomi kreatif guna menjamin hak ekonomi pencetus merupakan suatu hal yang penting. Kedua, saat ini peran pemerintah daerah dalam rangka memberikan pelindungan HKI bagi UKM dilakukan dengan membentuk Balai Pengelolaan Kekayaan Intelektual (BPKI), serta mengembangkan website guna memberikan pelayanan HKI, yaitu "JogjaKl".

Kata-kata Kunci: Hak kekayaan intelektual; pelayanan HKI; pelindungan hukum; UKM

${ }^{1}$ Penelitian Terapan Tahun 1 Dibiayai oleh DRPM Kementerian Riset Teknologi dan Pendidikan Tinggi Tahun Anggaran 2019 


\section{Pendahuluan}

Pelindungan hukum Hak Kekayaan Intelektual (HKI) merupakan hal yang penting dilaksanakan di Indonesia saat ini. Hal ini didasari alasan bahwa Indonesia memiliki potensi yang besardi bidang industri kreatif maupun kekayaan alam yang berlimpah, sehingga perlu didukung dengan upaya yang optimal dalam memberikan pelindungan HKI. Saat ini di Indonesia perkembangan industri kreatif cukup pesat dan mampu memberikan kontribusi bagi pertumbuhan ekonomi nasional.

Sumbangan ekonomi kreatif Indonesia terhadap Produk Domestik Bruto (PDB) yang hampir mencapai 8\% merupakan terbesar ketiga di dunia setelah Amerika Serikat (sekitar 11\%) dan Korea Selatan (sekitar 10\%), sehingga diyakini memperkuat Indonesia menempati urutan kelima perekonomian terbesar dunia pada 2030. ${ }^{2}$ Kontribusi ekonomi kreatif pada perekonomian nasional semakin nyata. Nilai tambah yang dihasilkan ekonomi kreatif juga mengalami peningkatan setiap tahun. Pertumbuhan sektor ekonomi kreatif yang sekitar 5,76 \%, menunjukkan berada di atas pertumbuhan sektor listrik, gas dan air bersih, pertambangan dan penggalian, pertanian, peternakan, kehutanan dan perikanan, jasa-jasa dan industri pengolahan. ${ }^{3}$ Kreativitas akan mendorong inovasi yang menciptakan nilai tambah lebih tinggi, dan pada saat yang bersamaan ramah lingkungan serta menguatkan citra dan identitas budaya bangsa.

Industri yang diyakini memiliki ketahanan atas terjadinya krisis keuangan global ini dikenal dengan industri kreatif. Membicarakan industri kreatif sangat berhubungan erat dengan pelindungan Kekayaan Intelektual (KI). Industri kreatif sangat sarat dengan kreativitas dan inovasi. Kreativitas dan inovasi ini dikenal dengan kekayaan intelektual. Mengingat dalam industri kreatif sarat dengan kekayaan intelektual, maka menjadi absolut jika kekayaan intelektual yang dimiliki industri kreatif sebelum dieksploitasi mendapatkan pelindungan dari segi hukum terlebih dahulu. Penghargaan atau hasil karya yang telah dihasilkan tentu diperlukan melalui pelindungan hukum bagi kekayaan intelektual tersebut.

\footnotetext{
${ }^{2}$ https://www.bekraf.go.id/berita/page/8/sumbangan-ekraf-terhadap-pdb-indonesia-terbesar-ketiga-didunia, diakses 9 November 2019

${ }^{3}$ https://kominfo.go.id/content/detail/5277/ekonomi-kreatif-adalah-pilar-perekonomian-masa-depan/

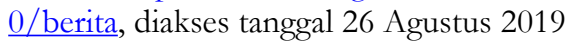


Tujuannya adalah untuk mendorong dan menumbuhkembangkan semangat terus berkarya dan mencipta.

Pelindungan hukum HKI pada negara berkembang seperti Indonesia belum menjadi perhatian yang serius, hal ini didasarkan pada rendahnya angka pengajuan permohonan HKI dan maraknya pelanggaran-pelanggaran hukum terhadap HKI. Faktor lainnya adalah kurangnya pemahaman dan pentingnya Hak Kekayaan Intelektual bagi industri kreatif seperti Usaha Kecil Menengah (UKM). Faktor ekonomi dalam HKI juga memengaruhi, karena tidak dapat diperoleh secara instan seperti halnya kegiatan bisnis pada umumnya. Selain itu, rendahnya pemahaman HKI juga dipengaruhi oleh perkembangan industri, teknologi dan ekonomi suatu negara. ${ }^{4}$ Efek pertumbuhan HKI dalam konteks ini berbeda-beda, bergantung pada waktu dan di berbagai daerah di dunia. ${ }^{5}$ Suatu barang atau jasa yang hari ini diproduksi di suatu negara, dapat dihadirkan di negara lain dalam kesempatan yang relatif singkat. Hadirnya barang dan jasa dalam proses produksi yang telah menggunakan HKI, dengan sendirinya memerlukan pelindungan terhadap HKI. ${ }^{6}$

Di DI Yogyakarta jumlah UKM terus mengalami peningkatan. Data terakhir pada 2017, di Yogyakarta terdapat sekitar 238.619 UKM yang tersebar di wilayah DI Yogyakarta. ${ }^{7}$ Pada 2018 jumlah UKM di Yogyakarta tercatat sebanyak 259.581 mengalami peningkatan dari tahun sebelumnya. ${ }^{8}$ Di Yogyakarta memiliki potensi usaha mikro dan kecil yang besar karena Yogyakarta merupakan kota pelajar dan kota yang mempunyai aset pariwisata budaya sehingga mendorong para pelaku usaha untuk membangun dan mengembangkan usahanya.

Pada 2017 lalu diperoleh data bahwa penyumbang Produk Domestik Regional Bruto di DIY dari sektor UKM yaitu sebesar 76,35\% dari keseluruhan

\footnotetext{
${ }^{4}$ Sanjaya Lall, "Indicators of the relative importance of IPRs in developing countries", Research Policy 32 (2003) 1657-1680, 2003, hlm. 1658

${ }^{5}$ World Bank, "Intellectual property: balancing incentives with competitive access. In: Global Economic Prospects". World Bank, Washington, DC, 2001, pp. 129-150, hlm. 135

${ }^{6}$ Hendra Tanu Atmadja, "Urgensi Pelindungan Hak Kekayaan Intelektual Dalam Era Perdagangan Bebas”, Jurnal Lex Jurnalica Volume 12 Nomor 3, Desember 2015, hlm 196

${ }^{7}$ http://www.depkop.go.id/uploads/tx_rtgfiles/22._Paparan_Rakornas_Yogyakarta_2018_-_DIY.pdf, diakses tanggal 27 Agustus 2019

${ }^{8}$ https://jogja.tribunnews.com/2019/10/11/ukm-diy-tumbuh-2-persen-per-tahun diakses tanggal 10 Maret 2020 .
} 
PDRB DIY, ${ }^{9}$ sehingga dapat dikatakan dari data tersebut bahwa UKM menjadi tulang punggung perekonomian di DIY saat ini. Berikut perkembangan data UKM di Yogyakarta dari 2015-2017:10

Tabel 1

Jumlah UKM DIY Tahun 2014-2015 ${ }^{11}$

\begin{tabular}{cc}
\hline Tahun & Jumlah \\
\hline 2015 & 220.703 \\
2016 & 230.047 \\
2017 & 238.619 \\
\hline
\end{tabular}

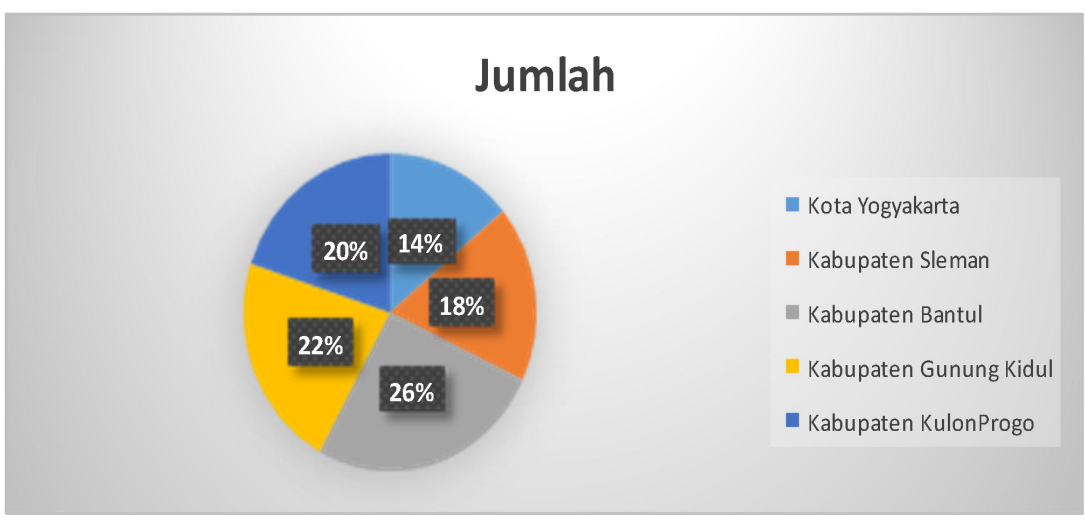

Grafik 2: Sebaran Jumlah UKM di DIY ${ }^{12}$

Berbagai kebijakan bagi UKM di Indonesia telah diimplementasikan melalui sejumlah peraturan perundang-undangan, dalam rangka menumbuhkembangkan iklim usaha. Diantaranya Undang-Undang Nomor 20 Tahun 2008 tentang Usaha Mikro, Kecil dan Menengah (UU UMKM) yang disusun dengan maksud sebagai upaya untuk meningkatkan kemampuan dan peran serta kelembagaan Usaha Mikro, Kecil, dan Menengah dalam perekonomian nasional. ${ }^{13}$ Dalam ketentuan Pasal 7 UU UKM ditegaskan bahwa Pemerintah dan Pemerintah Daerah menumbuhkan Iklim Usaha dengan menetapkan peraturan perundang-undangan dan kebijakan yang meliputi aspek: (1) pendanaan; (2) sarana dan prasarana; (3) informasi usaha; (4) kemitraan; (5) perizinan usaha; (6) kesempatan berusaha; (7) promosi dagang; dan (8) dukungan kelembagaan.

${ }^{9}$ Ibid.

${ }^{10}$ Ibid.

${ }^{11}$ Perkembangan Koperasi dan UKM di DIY, http://www.depkop.go.id/, diakses tanggal 15 November 2019

${ }^{12}$ Ibid.

${ }^{13}$ Lihat Penjelasan Umum UU No. 20 Tahun 2008 tentang Usaha Mikro, Kecil, dan Menengah 
Selain itu Pemerintah dan Pemerintah Daerah juga diperintahkan UU UKM untuk memfasilitasi pengembangan usaha dalam bidang: (1) produksi dan pengolahan; (2) pemasaran; (3) sumber daya manusia; dan (4) desain dan teknologi. Pemerintah dan Pemerintah Daerah juga diamanatkan untuk memfasilitasi pemilikan hak atas kekayaan intelektual atas produk dan desain Usaha Mikro, Kecil, dan Menengah padakegiatan usaha dalam negeri dan ekspor serta mendorong Usaha Mikro, Kecil, dan Menengah untuk memperoleh sertifikat hak atas kekayaan intelektual. ${ }^{14}$

Hak Kekayaan Intelektual merupakan hasil proses kemampuan berpikir manusia yang menjelma kedalam suatu ciptaan atau penemuan. Ciptaan atau penemuan tersebut merupakan milik yang diatasnya melekat suatu hak yang bersumber dari akal manusia. Hak tersebut digunakan atau dimanfaatkan oleh manusia untuk meningkatkan kesejahteraan atau kebahagiaan hidup. Makin maju dan tinggi tingkat kemampuan berpikir seseorang atau suatu bangsa, makin maju dan tinggi pula ilmu pengetahuan dan teknologi yang dikuasainya. Akibatnya, makin produktif pula seseorang atau bangsa menghasilkan ciptaan atau penemuan baru. ${ }^{15}$

Data yang diperoleh pada Dinas Perindustrian dan Perdagangan DI Yogyakarta pada 2019, bahwa UKM yang melakukan pendaftaran HKI masih sangat minim dibandingkan dengan jumlah UKM yang ada di Yogyakarta. Berikut data pendaftaran HKI bagi UKM sampai dengan Agustus 2019. ${ }^{16}$

Tabel 3

Jumlah UKM di DIY Yang Mandaftar HKI

\begin{tabular}{cc}
\hline Tahun & Jumlah \\
\hline 2016 & 42 \\
2017 & 183 \\
2018 & 183 \\
2019 & 176 \\
\hline
\end{tabular}
Usaha

${ }^{14}$ Lihat Pasal 14 ayat (1) huruf d dan Pasal 20 huruf e Undang-Undang Nomor 20 Tahun 2008 tentang

Mikro, Kecil dan Menengah.

15 Muhammad, Abdulkadir, Kajian Hukum Ekonomi Hak Kekayaan Intelektual, PT. Citra Aditya Bakti, Bandung, 2001, hlm. 9.

${ }^{16}$ Data dari Badan Pengelolaan Kekayaan Intelektual (BPKI), Dinas Perdagangan dan Perindustrian Propinsi DI Yogyakarta, Agustus 2019 
Sebagaimana diketahui bahwa Pelindungan atas Kekayaan Intelektual memiliki arti penting bagi dunia usaha. Dunia usaha membutuhkan pelindungan akan produknya dan apa saja yang berkaitan dengan produknya. ${ }^{17}$ Kekayaan intelektual merupakan kunci persaingan serta pengembangan sebuah usaha. Pemahaman akan Hak Kekayaan Intelektual (HKI) tidak hanya berguna untuk melindungi bisnis, tetapi juga menjaga agar suatu usaha tidak melanggar hukum akibat pelanggaran HKI. ${ }^{18}$ UKM sebagai pelaku ekonomi nasional yang mempunyai peran yang sangat penting dalam pembangunan perekonomian, ${ }^{19}$ hal ini dikarenakan kegiatan usahanya mampu memperluas lapangan kerja dan memberikan pelayanan ekonomi secara luas kepada masyarakat. ${ }^{20}$

Faktor yang menjadi kendala minimnya jumlah pendaftar HKI adalah birokrasi yang berbelit dan proses panjang sehingga kebanyakan UKM tidak sempat untuk datang ke Kantor Kementerian Hukum dan HAM DIY untuk melakukan pendaftaran, sehingga dengan demikian tujuan pelindungan terhadap industri kreatif menjadi tidak dapat tercapai. Maka, sudah sepatutnya UKM perlu memperoleh kesempatan yang sama dan bahkan harus diberikan keistimewaan khususnya di bidang kekayaan intelektual, dalam rangka pelindungan terhadap produk-produk kreatifnya di pasar bebas, dengan cara mempermudah birokrasi dan akses bagi UKM.

\section{Rumusan Masalah}

Berdasarkan uraian latar belakang di atas, maka permasalahan hukum yang menjadi fokus kajian dalam penelitian ini adalah: pertama, mengapa pelindungan hukum Hak Kekayaan Intelektual penting bagi Usaha Kecil

17 Sigit Nugroho, "Pelindungan Hak Kekayaan Intelektual Dalam Upaya Peningkatan Pembangunan Ekonomi Di Era Pasar Bebas Asean”, Jurnal Penelitian Hukum Supremasi Hukum, Vol. 24, No. 2, Agustus 2015, hlm. 166

18 Berinovasi.com, "Pentingnya Kekayaan Intelektual dalam Dunia Usaha", Berinovasi.com, http://berinovasi. com/wp-content/uploads/2018/01/Ebook-Pentingnya-Kekayaan-Intelektual-dalam-DuniaUsaha.pdf (diakses5 Agustus 2018).

19 Candra Purnama, "Pelindungan Hukum Produk UKM melalui HKI (Hak Kekayaan Intelektual)", Dinkop UKM Provinsi Jawa Tengah, http://dinkop-UKM.jatengprov.go.id/assets/upload/files/ HAK\%20MEREK\%20UKM. pdf (diakses 5 Agustus 2018)

${ }^{20}$ UKM sebagai salah satu pilar utama ekonomi nasional yang memberikan kontribusi terhadap Produk Domestik Bruto (PDB) yang sangat signifikan, tercatat pada akhir tahun 2017 kontribusi UKM terhadap PDB nasional adalah Rp 7.005.950 milyar atau sekitar 62,57\% dari total PDB. Lihat: Lei-KO2, "Ini Kontribusi Koperasi dan UKM Terhadap PDB Nasional 2017”, Legal Era.Id, https://legaleraindonesia.com/ini-kontribusikoperasi-danUKM- terhadap-pdb-nasional-2017/, (diakses 5 Agustus 2018) 
Menengah sebagai industri kreatif di Daerah Istimewa Yogyakarta? Kedua, bagaimana peran Pemerintah Daerah Daerah Istimewa Yogyakarta dalam rangka memberikan pelindungan hukum Hak Kekayaan Intelektual kepada Usaha Kecil Menengahdi Daerah Istimewa Yogyakarta?

\section{Tujuan Penelitian}

Penelitian ini bertujuan untuk: pertama, mengetahui dan menganalisis urgensi pelindungan hukum Hak Kekayaan Intelektual bagi Usaha Kecil Menengah sebagai industri kreatif di Daerah Istimewa Yogyakarta; Kedua, merumuskan peran Pemerintah Daerah Daerah Istimewa Yogyakarta dalam rangka memberikan pelindungan hukum Hak Kekayaan Intelektual bagi Usaha Kecil Menengah di Daerah Istimewa Yogyakarta.

\section{Metode Penelitian}

Metode yang digunakan dalam penelitian ini adalah metode penelitian hukum yuridis empiris. Penelitian yuridis empiris dilakukan dengan penelitian lapangan yang ditujukan pada penerapan aturan pelindungan HKI bagi industri kreatif dalam hal ini UKM yang ada di Yogyakarta, sehingga bisa melihat dan menganalisis terhadap arti penting pelindungan HKI bagi UKM. Pendekatan yuridis empiris disebut pula dengan penelitian lapangan, yaitu mengkaji ketentuan hukum yang berlaku serta apa yang terjadi dalam kenyataannya di masyarakat. Pendekatan ini dikenal pula dengan pendekatan secara sosiologis yang dilakukan secara langsung di lokasi penelitian, ${ }^{21}$ untuk mengetahui sejauh mana peranan lembaga terkait dalam membina kesadaran terhadap pentingnya pelindungan HKI dan memberikan pelayanan permohonan HKI bagi UKM.

Penelitian yuridis empiris, atau disebut dengan penelitian lapangan yaitu mengkaji ketentuan hukum yang berlaku serta apa yang terjadi dalam kenyataannya dalam masyarakat. ${ }^{22}$ Atau dengan kata lain yaitu suatu penelitian yang dilakukan terhadap keadaan sebenarnya atau keadaan nyata yang terjadi dimasyarakat dengan maksud untuk mengetahui dan menemukan fakta-fakta dan data yang dibutuhkan, setelah data yang dibutuhkan terkumpul kemudian

\footnotetext{
${ }^{21}$ Suharsimi Arikunto, Prosedur Penelitian Suatu Pendekatan Praktek, Jakarta, Rineka Cipta, 2012, hlm. 126

${ }^{22}$ Ibid
} 
menuju kepada identifikasi masalah yang pada akhirnya menuju pada penyelesaian masalah. ${ }^{23}$

Data primer penelitian ini adalah hasil penelitian di lapangan secara langsung. Yaitu data dari Balai Pengelolaan Kekayaan Intelektual DI Yogyakarta dengan melakukan wawancara dan pengambilan data-data dan dokumen secara langsung, yaitu dengan wawancara langsung terkait dengan permasalahan yang diteliti kepada narasumber yaitu Kepala Balai Pengelolaan Kekayaan Intelektual Dinas Perdagangan dan Perindustrian DI Yogyakarta. Setelah itu data yang diperoleh, dianalisis secara metode kualitatif yaitu memaparkan kenyataankenyataan yang didasarkan atas hasil penelitian. Dari analisis data tersebut, dilanjutkan dengan menarik kesimpulan motode induktif yaitu suatu cara berfikir khusus lalu kemudian diambil kesimpulan secara umum guna menjawab permasalahan yang diajukan.

\section{Hasil Penelitian dan Pembahasan}

\section{Pentingnya Pelindungan Hukum HKI Bagi UKM Sebagai Industri Kreatif di DIY}

Pelindungan hukum merupakan upaya untuk mengorganisasikan berbagai kepentingan dalam masyarakat supaya tidak terjadi tubrukan antar-kepentingan dan dapat menikmati semua hak-hak yang diberikan oleh hukum. ${ }^{24}$ Pelindungan hukum di sini akan dikaitkan dengan pelindungan hukum terhadap HKI bagi produk-produk industri kreatif UKM sesuai dengan ketentuan peraturan perundang-undangan HKI di Indonesia. Bila UKM telah memiliki pelindungan hukum terhadap produknya tentu akan memberikan kepastian hukum terhadap upaya memperjuangkan hak-haknya sebagai pihak yang memiliki hak terhadap produk tersebut.

Sektor UKM menjadi sumber pemasukan yang cukup potensial untuk daerah. Hal tersebut yang terjadi pula di Daerah Istimewa Yogyakarta (DIY) yang memiliki jumlah UKM cukup banyak, yaitu pada 2018 terdapat 258 ribu UKM

${ }^{23}$ Abdulkadir Muhammad, Hukum dan Penelitian Hukum, Bandung, Citra Aditya Bakti, 2004, hlm 134

${ }^{24}$ Satjipto Raharjo, Ilmu Hukum, Bandung: PT. Citra Aditya Bakti, 2000, hlm. 53-54. 
dan $90 \%$ nya merupakan pelaku usaha skala mikro. ${ }^{25}$ Peningkatan jumlah unit UKM secara terus-menerus pada tiap tahunnya membuktikan bahwa iklim usaha di DIY sesuai untuk perkembangan UKM itu sendiri.

UKM merupakan salah satu industri kreatif, yang dalam menjalankan usahanya akan menghasilkan produk-produk atau jasa-jasa kreatif. Sebagai suatu karya kreativitas, produk ekonomi kreatif merupakan kekayaan intelektual yang perlu mendapat penghargaan sebagai suatu karya intelektual yang memiliki nilai ekonomi dan perlu memperoleh pelindungan hukum.

Berbeda dengan karakteristik industri pada umumnya, industri ekonomi kreatif (ekraf) termasuk dalam kategori kelompok industri yang terdiri dari berbagai jenis industri yang masing-masing memiliki keterkaitan dalam proses pewujudan suatu ide atau gagasan menjadi suatu kekayaan intelektual (intellectual property). Industri kreatif mempunyai nilai ekonomi tinggi bagi kesejahteraan dan lapangan pekerjaan masyarakat serta dapat meningkatkan pertumbuhan ekonomi suatu negara. ${ }^{26}$ Produk ekonomi kreatif merupakan suatu kekayaan intelektual yang dihasilkan dan dimiliki oleh seorang pencipta dibidang seni, sastra dan ilmu pengetahuan atau seorang penemu dibidang teknologi (inventor). Oleh karenanya, produk ekraf merupakan suatu kekayaan yang perlu diberi penghargaan sebagai karya yang memiliki nilai ekonomi, sekaligus perlu mendapatkan pelindungan atas hak kekayaan intelektualnya.

Fakta bahwa potensi pasar karya kreatif di dalam dan luar negeri sangat besar dan memiliki kecenderungan terus berkembang. Hal ini semakin memperkuat alasan pentingnya pelindungan hak kekayaan intelektual (HKI) atas produk ekonomi kreatif dengan tujuan agar pencetus ide kreatif dan inovasi tersebut mendapatkan manfaat ekonomi atas karya intelektualnya.

Pada beberapa HKI seperti Merek, Paten, Desain Industri, Indikasi Geografis, permohonan pendaftaran merupakan syarat mutlak pelindungan HKI. Meskipun beberapa HKI lainnya seperti Hak Cipta dan Rahasia Dagang sistem pelindungan hukumnya melalui prinsip deklaratif. Saat ini pengajuan pendaftaran Merek

${ }^{25}$ Kepala Dinas Koperasi Usaha Kecil Menengah DIY, Srie Nurkyatsiwi, https://bisnis.tempo.co/read/ 1191330/UKM-yogya-belum-banyak-sentuh-e-commerce/full\&view=ok, diakses tanggal 11 November 2019

${ }^{26}$ Departemen Perdagangan Republik Indonesia, Pengembangan Ekonomi Kreatif Indonesia 2025, Depdag RI, Jakarta, 2008, hlm. .2 
untuk UKM masih mendominasi. Menurut Pasal 3 Undang-Undang Nomor 20 Tahun 2016 tentang Merek dan Indikasi Geografis ditentukan bahwa pelindungan atas merek diberikan setelah dilakukan pendaftaran. Sehingga pendaftaran merek merupakan hal yang penting dalam rangka pelindungan merek.

Di DIY pada saat ini telah ada kebijakan penerapan co-branding untuk produk UKM yang berasal dari DIY. Kebijakan tersebut tertuang dalam Peraturan Gubernur Nomor 21 Tahun 2017 tentang Penggunaan Merek Jogja Mark, 100\% Jogja dan Jogja Tradition Sebagai Co-Branding Produk Daerah. ${ }^{27}$ Tiga logo cobranding tersebut mempunyai spesifikasi berbeda. Logo Jogja Mark untuk produk atau jasa yang berbahan baku dari luar, tetapi proses produksinya di DIY. Logo 100\% Jogja khusus produk dan jasa yang bahan dan pengolahannya dari DIY, misalnya batik. Sedangkan Jogja Tradition untuk kreasi budaya yang berwujud benda maupun tak benda, seperti tarian, keris, dan blankon.

Syarat pengajuan co-branding antara lain pelaku usaha harus berdomisili di DIY, memiliki daftar perusahaan, memiliki Standar Operasional Prosedur (SOP) untuk dinilai kelayakannya mendapat co-branding. Pelaku UKM juga harus menyantumkan pernyataan tentang nama produk, asal bahan baku, serta proses produknya. Apabila ada ketidaksesuaian antara produk dan proses dengan pernyataan yang dicantumkan, maka ada sanksi. Strategi pemasaran dengan menggunakan dua merek atau lebih (co-branding) tersebut diharapkan bisa melindungi, melestarikan, dan mendokumentasikan produk-produk asal DIY dengan prosedur yang mudah. Saat ini terdapat tiga logo co-branding yang telah didaftarkan ke Direktorat Jenderal Kekayaan Intelektual (Dirjen KI), yaitu Jogja Mark, $100 \%$ Jogja, serta Jogja Tradition. ${ }^{28}$

Pada co-branding produk daerah dari DIY, ada yang hal mendasari dalam pelaksanaannya tersebut, yaitu: (1) untuk kepentingan masyarakat, demi mencapai masyarakat sejahtera dan mempunyai daya saing dengan produkproduk negara lain; (2) sulitnya mendaftarkan merek usaha bagi pelaku usaha UKM karena ketidakmampuannya pada bagian sumber daya manusia dan juga

\footnotetext{
${ }^{27}$ Dyah Permata Budi Asri, "Pengembangan Industri Kreatif UKM Asal Yogyakarta Melalui Pendaftaran Jogja Co Branding", Kosmik Hukum, 2018, hlm. 8

${ }^{28}$ Wawancara dengan Bapak Drs. Bambang Wahyu Indria, Kepala Balai Pelayanan Bisnis dan Pengelolaan Kekayaan Intelektual Disperindag DIY pada tanggal 17 Oktober 2017.
} 
biaya pendaftaran yang mahal; (3) untuk kepentingan seluruh masyarakat DIY, khususnya pegiat UKM dan industri ekonomi kreatif. ${ }^{29}$

Secara khusus tujuan yang ingin dicapai terhadap pemberlakuan co-branding tersebut adalah: (1) memberikan kejelasan hukum antara kekayaan inventor, pencipta, desainer, pemilik, pemakai, perantara yang menggunakannya, wilayah kerja pemanfaatannya, dan yang menerima akibat pemanfaatan HKI untuk jangka waktu tertentu; (2) memberikan penghargaan atas suatu keberhasilan usaha dalam upaya menciptakan suatu karya intelektual; (3) mempromosikan duplikasi invensi atau ciptaan dalam bentuk dokumen HKI yang terbuka bagi masyarakat; (4) merangsang terciptanya alih informasi melalui kekayaan intelektual serta alih teknologi melalui paten; (5) memberikan pelindungan terhadap kemungkinan ditiru karena adanya jaminan dari Pemerintahan Daerah di DIY. ${ }^{30}$

Usaha industri ekonomi kreatif sudah sangat berkembang saat ini, hal tersebut yang mendasari perlu pengaturan terkait pemakaian merek bersama untuk produk UKM yang difasilitasi oleh Dinas Perindustrian dan Perdagangan DIY melalui implementasi Peraturan Gubernur tersebut. Co-branding yang diterapkan bagi UKM di DIY juga merupakan merek pendamping. Dinas Perindustrian dan Perdagangan DIY melakukan koordinasi dan pengembangan merek bersama/co-branding, dan tentu saja dalam pelaksanannya diperlukan pengawasan dari pihak-pihak yang terkait karena co-branding di DIY ini terdiri dari berbagai produk baik yang sudah bermerek maupun yang belum bermerek.

Kendala dalam implementasi Peraturan Gubernur tersebut saat ini banyak ditemukan, antara lain adalah terhadap kebutuhan UKM terhadap merek bersama. Banyak UKM yang belum memahami arti pentingnya pelindungan merek produk lokal/produk asal DIY, sehingga pemahamandan pengimplementasian kebijakan tersebut masih sangat minim. Disinilah diperlukan peran Pemerintah Daerah DIY, terhadap pemahaman masyarakat UKM akan arti pentingnya pendaftaran merek bersama bagi produk unggulan daerah UKM. ${ }^{31}$

Pelaksanaan Peraturan Gubernur tentang Co-Branding di DIY diikuti dengan pembentukan Balai Pengelolaan Kekayaan Intelektual (BPKI) dibawah Dinas

\footnotetext{
${ }^{29}$ Ibid.

${ }^{30}$ Ibid.

${ }^{31}$ Ibid.
} 
Perdagangan dan Perindustrian DIY. BPKI dibentuk dengan dasar yaitu Peraturan Gubernur DIY Nomor 98 Tahun 2018 tentang Pembentukan, Susunan Organisasi, Tugas, Fungsi dan Tata Kerja Unit pelaksana Teknis Pada Dinas Perindustrian dan Perdagangan Daerah Istimewa Yogyakarta.

Pelayanan terhadap permohonan HKI bagi UKM telah dilakukan sejak 2011 lalu. Hingga per Agustus 2019, diperoleh data berikut ini baik merupakan pengajuan HKI UKM, Permohonan Co-Branding, Fasilitasi HKI, Permohonan Rekomendasi, Konsultasi HKI, dan Advokasi. Secara lengkap akan disajikan dalam tabel-tabel berikut ini:

Tabel 5 Pengajuan HKI di DIY ${ }^{32}$

\begin{tabular}{llr}
\hline No. & \multicolumn{1}{c}{ Kabupaten } & Jumlah \\
\hline 1 & Kota Yogyakarta & 328 \\
2 & Kabupaten Sleman & 227 \\
3 & Kabupaten Bantul & 177 \\
4 & Kabupaten Gunung Kidul & 42 \\
5 & Kabupaten Kulon Progo & 55 \\
6 & Lain-lain & 10 \\
\hline
\end{tabular}

Tabel 6 Pengajuan Co-Branding ${ }^{33}$

\begin{tabular}{llr}
\hline No. & Kabupaten & Jumlah \\
\hline 1 & Kota Yogyakarta & 53 \\
2 & Kabupaten Sleman & 28 \\
3 & Kabupaten Bantul & 50 \\
4 & Kabupaten Gunung Kidul & 4 \\
5 & Kabupaten Kulon Progo & 14 \\
\hline
\end{tabular}

Berdasarkan data-data pada tabel 5 dan 6 di atas, pengajuan HKI terbesar ada di Kota Yogyakarta, dan yang terkecil ada di Kulon Progo. Sedangkan untuk pengajuan HKI lain-lain berasal dari luar DIY. Untuk pengajuan Co-Branding, telah dilaksanakan melalui BPKI, dan pengajuan terbesar berjumlah 53 yang berasal dari Kota Yogyakarta, sedangkan terkecil dari Kabupaten Kulonprogo berjumlah 14. Sedangan rincian dari pengajuan Co-Branding ini ada pada grafik berikut:

\footnotetext{
${ }^{32}$ https://disperindag.jogjaprov.go.id/haki/statistik_haki.asp, diakses tanggal 11 November 2019

${ }^{33}$ Ibid.
} 
Grafik 7 Lisensi Co Branding ${ }^{34}$

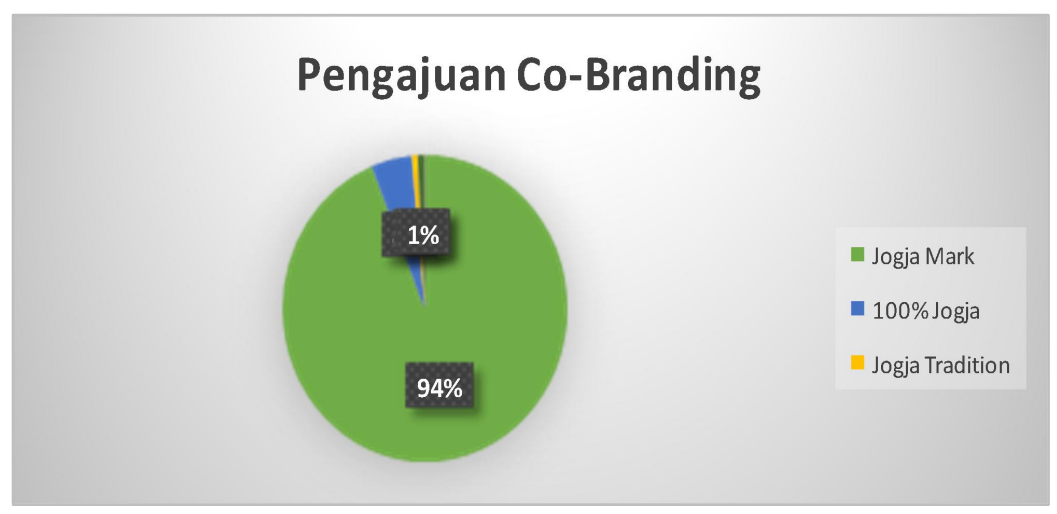

Dari data-data yang disajikan di atas, fasilitasi terhadap pelayanan pendaftaran HKI telah dilaksanakan oleh BPKI, yang terdiri dari pendaftaran Jogja Mark sebesar 94\%, pendaftaran 100\% Jogja sebesar 4\% dan pendaftaran Jogja Traditional sebanyak 1\%, baik pendaftaran HKI pribadi UKM maupun dengan fasilitasi dari BPKI sesuai dengan kuota yang telah ditentukan per tahun anggarannya. Selain itu dari BPKI juga telah mengeluarkan surat rekomendasi bagi UKM untuk melakukan pendaftaran HKI sehingga khusus bagi UKM ada keringanan pembiayaan pendaftaran HKI. Pemberian surat rekomendasi pendaftaran HKI bagi UKM telah dikeluarkan oleh BPKI hingga saat ini berjumlah 100 surat rekomendasi. ${ }^{35}$

Berbagai program dan fasilitas dari BPKI terhadap perolehan pendaftaran HKI bagi UKM dengan tujuan untuk meningkatkan kesadaran maupun pelindungan hukum bagi produk/jasa kreatif UKM telah dilaksanakan. Namun jika dilihat dari jumlah UKM di DIY saat ini yang mencapai lebih dari 200 ribu UKM, jumlah perolehan HKI bagi UKM masih sangat minim/rendah.Perlu upaya yang lebih optimal lagi guna mencapai tujuan pelindungan hukum bagi produk kreatif UKM, salah satunya dengan mempermudah akses kemudahan bagi UKM untuk bisa mengetahui syarat/informasi maupun proses pendaftaran HKI dimanapun dan kapanpun tanpa menganggu aktivitas bisnis UKM.

\footnotetext{
${ }^{34}$ Ibid.

${ }^{35}$ Wawancara dengan Drs. Bambang Wahyu Indria, Kepala Balai Pengelolaan Kekayaan Intelektual (BPKI) Disperindag DIY pada tanggal 26 Agustus 2019.
} 
Akses kemudahan bagi UKM dilakukan dengan pelayanan dan pendaftaran HKI secara online berbasis website. Pergub Jogja Co Branding perlu disosialisasikan kepada UKM tentang adanya fasilitasi pendaftaran HKI dalam rangka mengefektifkan pendaftaran HKI bagi UKM. Pergub tersebut juga perlu dilakukan perbaikan terutama untuk mendorong kesadaran UKM dalam melakukan pendaftaran HKI. Perbaikan tersebut antara lain mengatur adanya tim khusus yang bertugas mendampingi UKM untuk melakukan proses pendaftaran HKI.

\section{Peran Pemerintah Daerah DIY dalam Memberikan Pelindungan HKI kepada UKM di DIY}

HKI adalah hak yang berkenaan dengan kekayaan yang timbul karena kemampuan intelektual manusia. Kemampuan tersebut dapat berupa karya dibidang teknologi, ilmu pengetahuan, seni dan sastra. ${ }^{36}$ Secara garis besar ruang lingkup hak kekayaan intelektual dibagi menjadi dua, yaitu hak cipta dan hak kekayaan industri. Hak cipta terdiri dari ilmu pengetahuan, seni, dan sastra. Hak kekayaan industri terdiri dari paten, merek, desain industri, desain tata letak sirkuit terpadu, rahasia dagang, dan pelindungan varietas tanaman. ${ }^{37}$

Fourth Industrial Revolution ("4IR") atauRevolusi Industri 4.0 tidak hanya berpotensi luar biasa dalam merombak industri, tapi juga mengubah berbagai aspek kehidupan manusia. Industri 4.0 adalah sebuah istilah yang diciptakan pertama kali di Jerman pada 2011 yang ditandai dengan revolusi digital. Industri ini merupakan suatu proses industri yang terhubung secara digital yang mencakup berbagai jenis teknologi, mulai dari 3D printing hingga robotik yang diyakini mampu meningkatkan produktivitas. ${ }^{38}$ Industri ini merupakan suatu proses industri yang terhubung secara digital yang mencakup berbagai jenis teknologi, mulai dari 3D printing hingga robotik yang diyakini mampu meningkatkan produktivitas.

\footnotetext{
${ }^{36}$ Muhammad Ahkmad Subroto \& Suprapedi, Pengenalan HKI (Hak Kekayaan Intelektual) Konsep Dasar Kekayaan Intelektual untuk Penumbuhan Inovasi, PT Indeks, Jakarta, 2008, hlm. 14

${ }^{37}$ Much. Nurachmad, Segala Tentang HAKI Indonesia, Buku Biru, Yogyakarta, 2012, hlm. 22.

${ }^{38}$ Venti Eka Satya, "Strategi Indonesia Menghadapi Industri 4.0", Jurnal Info Singkat Bidang Ekonomi dan Kebijakan Publik, Vol. X, No. 09/I/Puslit/Mei/2018, hlm. 19.
} 
Sebelum ini telah terjadi tiga revolusi industri yang ditandai dengan beberapa hal, yaitu: (1) ditemukannya mesin uap dan kereta api 1750-1930; (2) penemuan listrik, alat komunikasi, kimia, dan minyak 1870-1900; (3) penemuan komputer, internet, dan telepon genggam 1960-sekarang. ${ }^{39}$ Lompatan besar terjadi dalam sektor industri di era revolusi industri keempat. Teknologi informasi dan komunikasi dimanfaatkan sepenuhnya. Pada era ini model bisnis mengalami perubahan besar, tidak hanya dalam proses produksi, melainkan juga di seluruh rantai nilai industri.

Kementerian Perindustrian telah menetapkan empat langkah strategis dalam menghadapi Industri 4.0. Langkah-langkah yang akan dilaksanakan tersebut adalah:

Pertama, mendorong agar angkatan kerja di Indonesia terus meningkatkan kemampuan dan keterampilannya, terutama dalam menggunakan teknologi internet of things atau mengintegrasikan kemampuan internet dengan lini produksi di industri;

Kedua, pemanfaatan teknologi digital untuk memacu produktivitas dan daya saing bagi industri kecil dan menengah (IKM) agar mampu menembus pasar ekspor melalui program E-smart IKM.

Ketiga, pemanfaatan teknologi digital yang lebih optimal dalam perindustrian nasional seperti Big Data, Autonomous Robots, Cybersecurity, Cloud, dan Augmented Reality.

Keempat, mendorong inovasi teknologi melalui pengembangan start up dengan memfasilitasi inkubasi bisnis agar lebih banyak wirausaha berbasis teknologi di wilayah Indonesia. ${ }^{40}$

Dari keempat langkah strategis yang telah ditentukan oleh Kementerian Perindustrian dalam menghadapi Industri 4.0, langkah kedua yaitu pemanfaatan teknologi digital untuk memacu produktivitas dan daya saing bagi UKM dalam menembus pasar global, akan menjadi fokus dalam tulisan ini. Di atas kertas, pemerintah Indonesia tampak serius dalam mendorong sektor bisnis untuk beradaptasi dengan era Industri Keempat atau Industri 4.0 yang didominasi oleh konektivitas. Internet menjadi sesuatu yang tak bisa dipisahkan dari era ini.

Pelayanan HKI bagi UKM ini juga sudah semestinya memanfaatkan konektivitas internet supaya lebih memudahkan akses bagi UKM dan tidak membatasi wilayah dan waktu, dalam arti dapat mengakses dimanapun dan 
kapanpun. Perlu dibangun suatu sistem agar UKM dapat dengan mudah dan segera mengakses permohonan pendaftaran HKI dengan tidak mengurangi aktivitas bisnis yang dilakukan di tempat yang berbeda. Fasilitas layanan HKI tersebut berbasis website atau online system.

Selain bermanfaat untuk mempermudah akses pendaftaran HKI bagi UKM, pendaftaran HKI melalui online system juga akan menjadi sarana penyimpanan data UKM yang mudah dan akurat. Hal demikian sering disebut dengan istilah komputasi awan. Meskipun demikian selain ada keuntungan terhadap proses pengajuan pendaftaran HKI secara online, kendala yang mungkin dialami adalah sistem ini sangat tergantung dengan jaringan internet, sehingga jika ada gangguan terhadap jaringan internet maka akan terkendala terhadap proses pendaftaran ini.

Pada Balai Pengelolaan Kekayaan Intelektual DIY, saat ini tengah dikembangkan website yang bisa dimanfaatkan guna melakukan sosialisasi, permohonan pengajuan HKI dan penyimpanan database UKM. Website tersebut diberi nama dengan Jogja KI Layanan Kekayaan Intelektual Online, yang dikembangkan melalui penelitian ini.

BPKI yang struktur organisasinya terdiri atas kepala, kelompok jabatan fungsional, sub bagian tata usaha, seksi fasilitas kekayaan intelektual, dan seksi pemberdayaan kekayaan intelektual bertugas melaksanakan pengelolaan kekayaan intelektual untuk meningkatkan jumlah HKI terdaftar dari industri kecil menengah atau sentra yang dibina. Adapun fungsi BPKI ialah: ${ }^{41}$ (1) penyusunan rencana kerja Balai; (2) pemberdayaan potensi kekayaan intelektual; (3) pembinaan dan advokasi kekayaan intelektual; (4) pengelolaan sistem manajemen informasi kekayaan intelektual; (5) pembinaan sentra kekayaan intelektual; (6) pelaksanaan fasilitasi kekayaan intelektual; (7) pelaksanaan ketatausahaan; (8) pemantauan, evaluasi dan penyusunan laporan program Balai; (9) pelaksanaan tugas lainnya yang diberikan oleh atasan sesuai dengan tugas dan fungsi UPT.

${ }^{41}$ https:// disperindag.jogjaprov.go.id/haki/tupoksi.asp, diakses tanggal 11 November 2019. 
Selama ini BPKI berperan dalam memberikan pelayanan terhadap UKM seperti: (1) Konsultasi Hak Kekayaan Intelektual (KONKI); (2) fasilitasi pendaftaran HKI; (3) penerbitan rekomendasi IKM; (4) penerbitan lisensi Co Branding; dan (4) advokasi. Sedangkan untuk melaksanakan peran dan fungsinya BPKI juga melakukan dan membina hubungan dengan berbagai instansi maupun mitra kerja yaitu:(1) Direktorat Jenderal Kekayaan Intelektual Kementerian Hukum dan HAM; (2) Kementerian Perindustrian; (3) Kementerian Perdagangan; (4) Kanwil DIY Kementerian Hukum dan HAM; (5) Kementerian Riset Teknologi dan Pendidikan Tinggi; (6) Badan Ekonomi Kreatif; (7) SKPD Terkait (DIY \& Kabupaten/Kota); (8) Asosiasi Sentra Kekayaan Intelektual Indonesia (ASKII); (10) Sentra HKI Perguruan Tinggi, meliputi: UGM, UII, UPN Veteran, UIN Suka, UMY, Universitas Janabadra Yogyakarta, STMIK "Amikom" Yogyakarta, Akademi Perindustrian, UNY, UAD; dan (11) Pelaku Usaha/UKM. ${ }^{42}$

Aplikasi layanan HKI merupakan aplikasi yang dikembangkan pada BPKI Dinas Perindustrian dan Perdagangan DIY. Aplikasi ini untuk mempermudah pelayanan Pendaftaran Co Branding dan Pendaftaran Fasilitasi dan Rekomendasi HKI serta menyampaikan berita, informasi dan agenda yang ada di BPKI. Website JogjaKI dapat diakses melalui url: https://jogjaki.jogjaprov.go.id.

Fitur-fitur yang tersedia pada layanan pendaftaran HKI tersebut adalah: (1) Profil, untuk melihat profil BPKI yang berisi Visi dan Misi, Tugas Pokok dan Fungsi serta, Struktur Organisasi; (2) Berita, untuk melihat berita-berita seputar HKI dan BPKI; (3) Informasi dan Agenda, berisi tentang Infomasi dan agenta tentang HKI, Co Branding dan Agenda kedinasan Pemda DIY; (4) Data, untuk menampilkan jumlah data yang telah mendaftar Co Branding dan HKI melalui BPKI; (5) Pendaftaran, digunakan untuk melakukan pendaftaran Fasilitasi dan Rekomendasi HKI dan Pendaftaran Lisensi Co Branding; (6) Kontak Kami, untuk menghubungi BPKI.

Adanya aplikasi/sistem ini diharapkan mampu mempermudah pendaftaran HKI bagi UKM. Aplikasi ini tentu diharapkan dapat mempermudah UKM yang tersebar di berbagai wilayah DIY dalam mencari informasi tentang pendaftaran

\footnotetext{
${ }^{42}$ Wawancara dengan Drs. Bambang Wahyu Indria, Kepala Balai Pelayanan Bisnis dan Pengelolaan Kekayaan Intelektual Disperindag DIY pada tanggal 17 Oktober 2017.
} 
HKI, bahkan melakukan pendaftaran HKI dimanapun dan kapanpun tanpa mengganggu aktivitas bisnis mereka. Meskipun demikian, BPKI berupaya tetap menyediakan fasilitas pendaftaran secara offline, dengan membuka counter pelayanan pendaftaran HKI untuk mengantisipasi pendaftaran HKI yang terkendala jaringan internet.

Pentingnya pelindungan merek mendorong kemudahan bagi UKM agar tidak harus mendatangi kantor BPKI pada saat akan mengajukan permohonan pendaftaran HKI, tidak harus membawa banyak dokumen-dokumen pengajuan HKI, serta pendaftaran dapat dilakukan dimanapun juga di tempat tinggal atau tempat usaha UKM. Fasilitas pendaftaran HKI secara onlinebagi UKM yang disediakan oleh pemerintah daerah DIY melalui BPKI ini diharapkan dapat memacu peningkatan permohonan pendaftaran bagi UKM.

Langkah pertama atas kehadiran website Layanan KI ini tentunya adalah dengan melakukan sosialisasi, pendampingan dan pelatihan-pelatihan bagi UKM dalam memanfaatkan akses Layanan Jogja KI. Tantangan kedepannya perlu dikembangkan untuk mempermudah akses ini melalui sistem pendafataran HKI berbasis sistem android/IOS. Pendaftaran HKI secara online melalui Website, tidak mereduksi ketentuan hukum pendaftaran HKI, karena pendaftaran online ini tetap memberlakukan syarat-syarat pendaftaran HKI sesuai dengan ketentuan undang-undang, hanya dilakukan secara online sehingga memudahkan bagi UKM.

\section{Penutup}

Berdasarkan hal-hal yang diuraikan dalam penelitian dan pembahasan maka dapat disimpulkan: pertama, potensi pasar karya industri kreatif memiliki kecenderungan terus berkembang, sehingga pelindungan HKI atas produk ekonomi kreatif guna menjamin hak ekonomi pencetus merupakan suatu hal yang penting. Pelindungan HKI bagi produk UKM di DIY telah disadari arti pentingnya oleh pemerintah daerah, sebagaimana kebijakan daerah dalam penerapan co-branding untuk produk UKM yang berasal dari DIY. Kebijakan tersebut tertuang dalam Peraturan Gubernur Nomor 21 Tahun 2017 tentang Penggunaan Merek Jogja Mark, 100\% Jogja dan Jogja Tradition Sebagai CoBranding Produk Daerah. Pelindungan HKI terhadap produk kreatif di DIY 
semakin penting dan dibutuhkan, karena pertumbuhan UKM di DIY selalu berkembang tiap tahunnya dan hampir 59\% produk kreatif UKM menjadi penyumbang Pendapatan Bruto Daerah.

Kedua, peran pemerintah daerah dalam memberikan pelindungan hukum atas HKI bagi UKM salah satunya dilakukan melalui BPKI Dinas Perdagangan dan Perindustrian DIY. Pendaftaran HKI sebagai pintu masuk pelindungan hukum telah difasilitasi oleh BPKI DIY dengan sistem online, yang diharapkan dapat mempermudah UKM mengakses permohonan pendaftaran HKI. Aplikasi layanan HKI ini berfungsi untuk mempermudah pelayanan dalam proses pendaftaran co branding dan pendaftaran fasilitasi dan rekomendasi HKI serta menyampaikan berita, informasi dan agenda BPKI. Agar tujuan pemerintah daerah dalam memberikan pelindungan hukum HKI bagi UKM di DIY dapat tercapai, maka perlu selalu dilakukan pendampingan dan pelatihan pengajuan HKI secara online melalui Jogja KI.

\section{Daftar Pustaka}

\section{Buku}

Arikunto, Suharsimi, Prosedur Penelitian Suatu Pendekatan Praktek, Rineka Cipta, Jakarta, 2012.

Departemen Perdagangan Republik Indonesia, Pengembangan Ekonomi Kreatif Indonesia 2025, Depdag RI, Jakarta, 2008.

Muhammad, Abdulkadir, Kajian Hukum Ekonomi Hak Kekayaan Intelektual, PT. Citra Aditya Bakti, Bandung, 2001. , Hukum dan Penelitian Hukum, Citra Aditya Bakti, Bandung, 2004.

Nurachmad, Much., Segala Tentang HAKI Indonesia, Buku Biru, Yogyakarta, 2012.

Raharjo, Satjipto, Ilmu Hukum, PT. Citra Aditya Bakti, Bandung, 2000.

Subroto, Muhammad Ahkmad, \& Suprapedi, Pengenalan HKI (Hak Kekayaan Intelektual) Konsep Dasar Kekayaan Intelektual untuk Penumbuhan Inovasi, PT Indeks, Jakarta, 2008.

World Bank, Intellectual property: balancing incentives with competitive access. In: Global Economic Prospects. World Bank, Washington, DC, hlm. 129-150.

\section{Jurnal}

Asri, D. P. B. “Pengembangan Industri Kreatif UKM Asal Yogyakarta Melalui Pendaftaran Jogja Co Branding". Kosmik Hukum, 18(2), 2018 
Atmadja, Hendra Tanu, “Urgensi Pelindungan Hak Kekayaan Intelektual Dalam Era Perdagangan Bebas", Jurnal Lex Jurnalica Volume 12 Nomor 3, Desember 2015

Lall, Sanjaya, "Indicators of The Relative Importance of IPRs in Developing Countries", Research Policy 32 (2003) 1657-1680, 2003

Nugroho, Sigit, "Pelindungan Hak Kekayaan Intelektual Dalam Upaya Peningkatan Pembangunan Ekonomi Di Era Pasar Bebas Asean", Jurnal Penelitian Hukum Supremasi Hukum, Vol. 24, No. 2, Agustus 2015

Satya, Venti Eka, “Strategi Indonesia Menghadapi Industri 4.0”, Jurnal Info Singkat Bidang Ekonomi dan Kebijakan Publik, Vol. X, No. 09/I/Puslit/Mei/2018

\section{Peraturan Hukum}

Undang-Undang Nomor 20 Tahun 2016 tentang Merek dan Indikasi Geografis

Undang Undang Nomor 20 Tahun 2008 tentang Usaha Mikro, Kecil dan Menengah

Peraturan Gubernur DIY Nomor 21 Tahun 2017 tentang Penggunaan Merek Jogja Mark, 100\% Jogja dan Jogja Tradition Sebagai Co-Branding Produk Daerah

Peraturan Gubernur DIY Nomor 98 Tahun 2018 tentang Pembentukan, Susunan Organisasi, Tugas, Fungsi dan Tata Kerja Unit pelaksana Teknis Pada Dinas Perindustrian dan Perdagangan Daerah Istimewa Yogyakarta.

\section{Internet}

https:/ / kominfo.go.id/content/detail/5277/ekonomi-kreatif-adalah-pilarperekonomian-masa-depan/0/ berita, diakses tanggal 26 Agustus 2019

Eka Mei Ristianti, "Hak Atas Kekayaan Intelektual (HaKI) Dalam Dunia Teknologi Industri Berbasis Revolusi 4.0 Di Indonesia", https://www.researchgate.net/publication/330570782_Hak_Atas_Kekay aan_Intelektual_Haki_Dalam_Dunia_Teknologi_Industri_Berbasis_Revol usi_40_Di_Indonesia

http://www.depkop.go.id/uploads/tx_rtgfiles/22._Paparan_Rakornas_Yogyaka rta_2018_-_DIY.pdf, diakses tanggal 27 Agustus 2019

https:/ /jogja.tribunnews.com/2019/10/11/ukm-diy-tumbuh-2-persen-per-tahun diakses tanggal 10 Maret 2020.

Berinovasi.com,"PentingnyaKekayaan Intelektual dalam Dunia Usaha" , Berinovasi.com, http://berinovasi.com/wp-content/uploads/2018/01/ EbookPentingnya-Kekayaan-Intelektual-dalam-Dunia-Usaha.pdf, diakses 5 Agustus 2018

Candra Purnama,"Pelindungan Hukum Produk UKM melalui HKI (Hak Kekayaan Intelektual)", Dinkop UKM Provinsi Jawa Tengah, 
http://dinkop UKM.jatengprov.go.id/assets/upload/files/HAK\%20 MEREK\%20UKM. pdf, diakses 5 Agustus 2018

https:// www.antaranews.com/berita/831360/bekraf-perkembangan-industrikreatif-cukup-pesat, diakses tanggal 26 Agustus 2019

UKM sebagai salah satu pilar utama ekonomi nasional yang memberikan kontribusi terhadap Produk Domestik Bruto (PDB) yang sangat signifikan, tercatat pada akhir tahun 2017 kontribusi UKM terhadap PDB nasional adalah Rp 7.005.950 milyar atau sekitar 62,57\% dari total PDB. Lihat: LeiKO2, "Ini Kontribusi Koperasi dan UKM Terhadap PDB Nasional 2017", Legal Era.Id, https://legaleraindonesia.com/ini-kontribusi-koperasidanUKM- terhadap-pdb-nasional-2017/, diakses 5 Agustus 2018

Perkembangan Koperasi dan UKM di DIY, http://www.depkop.go.id/, diakses tanggal 15 November 2019 